\title{
PENERAPAN PEMBELAJARAN KOOPERATIF TIPE JIGSAW TERHADAP HASIL BELAJAR SISWA DALAM MATA PELAJARAN SEJARAH KELAS XI IPS \\ DI SMANEGERI 14 BATAM TAHUN PELAJARAN 2013/2014
}

\author{
Kartika Putri Adi, Afrinel Okwita*, Tri Tarwiyani \\ *Dosen Pendidikan Sejarah, FKIP-UNRIKA \\ aaftuteh@gmailcom
}

\begin{abstract}
Pembelajaran yang terpusat pada guru berdampak terhadap kurang optimalnya kemampuan berfikir siswa. Selain itu, siswa juga sulit untuk memahami materi pembelajaran dari bahan ajar yang telah disediakan sehingga siswa menjadi pelajar pasif. Penelitian ini bertujuan untuk mengungkapkan hasil belajar siswa pada mata pelajaran sejarah melalui pembelajaran kooperatif tipe Jigsaw dan mengetahui perbedaan hasil belajar siswa kelas eksperimen dan kelas kontrol di SMA Negeri 14 Batam. Jenis penelitian ini adalah penelitian kuantitatif dengan pendekatan Quasi Experimental Design. Subjek penelitian ini adalah seluruh siswa kelas XI IPS 3 sebagai kelas eksperimen dengan jumlah 30 orang dan kelas XI IPS 2 sebagai kelas kontrol yang berjumlah 30 orang. Pengambilan kelas sampel ini dilakukan secara acak dari kelas yang ada. Hasil uji coba instrumen yang terdiri dari 40 butir soal objektif yang di uji cobakan terdapat 25 butir soal yang valid dan digunakan sebagai soal post test pada kelas sampel. Data yang diperoleh dari hasil post test dianalisis menggunakan uji perbedaan rata-rata (uji-t). Hasil penelitian ini menunjukkan bahwa terdapat perbedaan yang signifikan terhadap hasil belajar siswa pada kelas eksperimen dan kontrol, dimana rata-rata nilai dari kelas eksperimen adalah 73,07 sedangkan pada kelas kontrol mempunyai ratarata 66,66. Dengan analisis uji-t diperoleh thitung sebesar 2,1084 pada signifikansi 0,05 dan tabel sebesar 1,671 karena nilai thitung $>$ tabel sehingga dapat disimpulkan bahwa pembelajaran kooperatif tipa Jigsaw memiliki perbedaan yang signifikan terhadap hasil belajar siswa kelas eksperimen dan kelas kontrol pada mata pelajaran sejarah di SMA Negeri 14Batam.
\end{abstract}

Kata kunci : Pembelajaran Kooperatif Tipe Jigsaw, Hasil Belajar, Mata Pelajaran Sejarah.

\section{A. PENDAHULUAN}

Menurut Mudyahardjo (2001: 11) pendidikan adalah usaha sadar yang dilakukan oleh keluarga, masyarakat, dan pemerintah, melalui kegiatan bimbingan, pengajaran, dan latihan, yang berlangsung di sekolah dan di luar sekolah sepanjang hayat untuk mempersiapkan peserta didik agar dapat memainkan peran dalam berbagai lingkungan hidup secara tepat di masa yang akan datang. Pendidikan diharapkan akan memberikan kemampuan setiap orang 
untuk memahami berbagai aspek lingkungan agar manusia dapat hidup dengan harkat dan martabatnya dalam rangka mengembangkan keterampilan kerja dan berkomunikasi dengan berbagai pihak yang diperlukan (Aunurrahman, 2008: 5). Melalui pendidikan manusia mampu mengembangkan dirinya serta dapat meningkatkan harkat dan martabat manusia sehingga mampu untuk menghadapi perubahan yang terjadi menuju ke arah yang lebih baik. Pendidikan mempunyai andil yang besar dalam upaya mencerdaskan manusia dan dalam upaya mensukseskan pembangunan nasioanal. Begitu pentingnya pendidikan di Indonesia, membuat pemerintah melakukan berbagai upaya dalam meningkatkan mutu pendidikan yaitu dengan perbaikan sarana dan prasarana, sistem dan pendekatan pembelajaran, perubahan kurikulum, teknik evaluasi, dan pelaksanaan pendidikan menjadi lebih baik.

Selain uapaya peningkatan mutu pendidikan yang dilakukan oleh pemerintah maka, guru juga dapat melakukan perbaikan mutu pendidikan yang ada. Menurut Kamdi (dalam Annurrahman, 2008: 2) salah satunya dengan mendesain pembelajaran menantang dan menarik untuk mencapai derajat berfikir tingkat tinggi. Guru dapat mendesain pembelajaran yang menarik berupa penggunaan metode-metode pembelajaran yang digunakan pada saat proses belajar mengajar. Pada kenyataannya selama ini penggunaan metode pembelajaran yang bervariasi pada proses belajar mengajar mampu menunjang hasil belajar siswa. Sampai saat ini pendidikan di Indonesia belum menunjukkan hasil yang memuaskan. Rendahnya hasil belajar disebabkan oleh berbagai faktor, seperti minat, bakat, motivasi, intelegensi, kebiasaan belajar, dan faktor psikologis lainnya. Salah satu contohnya di sekolah SMA Negeri 14 Batam pada Mata Pelajaran Sejarah, siswa mudah jenuh dan bosan dalam belajar, sehingga hasil belajar Sejarah menjadi rendah.

Sejarah merupakan cabang ilmu pengetahuan yang menelaah tentang asalusul dan perkembangan serta peranan masyarakat di masa lampau berdasarkan metode dan metodelogi tertentu. Mata Pelajaran Sejarah memiliki arti dalam membentuk watak dan peradaban bangsa yang bermartabat serta dalam membentuk manusia Indonesia yang memiliki rasa kebangsaan dan cinta tanah air (Sapriyani, 2012: 208-209).

Tujuan sekolah SMA Negeri 14 Batam sebagai bagian dari tujuan pendidikan nasional adalah meningkatkan kecerdasan, pengetahuan, kepribadian, akhlak mulia, serta keterampilan untuk hidup mandiri dan mengikuti pendidikan lebih lanjut (Dokumentasi Tata Usaha SMA N 14, diakses tanggal 20 November2013). Namun kenyataannya, sulit untuk mencapai tujuan SMA Negeri 14 Batam ini.

Faktor lain yang menyebabkan banyaknya siswa mendapat nilai di bawahKKM adalah kurang aktifnya siswa dalam proses pembelajaran seperti bertanya, menjawab 
pertanyaan, dan lainnya. Siswa hanya bergantung pada materi yang disampaikan oleh guru sehingga guru menjadi faktor yang dominan dalam proses belajar pembelajaran. Guru seharusnya mampu menerapkan berbagai model pembelajaran yang inovatif sehingga pembelajaran sejarah menjadi menarik.

Keberadaan peran dan fungsi guru dalam dunia pendidikan merupakan salah satu faktor yang sangat signifikan. Guru merupakan bagian terpenting dalam proses belajar mengajar, baik di jalur pendidikan formal maupun informal. Oleh sebab itu, dalam setiap upaya peningkatan kualitas pendidikan di tanah air, tidak dapat dilepaskan dari berbagai hal yang berkaitan dengan eksistensi guru itu sendiri (Daryanto, 2013:1).

Menurut Glasser (dalam Rusman, 2013: 53) menyatakan berkenaan dengan kemampuan guru, ada empat hal yang harus dikuasai oleh guru yaitu : menguasai bahan pelajaran, mampu mendiagnosis tingkah laku siswa, mampu melaksanakan proses pembelajaran, dan mampu mengevaluasi hasil belajar siswa. Pembelajaran yang menyenangkan dapat meningkatkan mutu pendidikan. Hal ini disebabkan karena siswa lebih tertarik untuk belajar. Banyak upaya yang dapat lakukan oleh guru untuk membuat pembelajaran menjadi menarik. Salah satunya dengan menggunakan model pembelajaran yang inovatif. Banyak model pembelajaran yang digunakan oleh guru dalam proses belajar pembelajaran, salah satu diantaranya adalah model pembelajaran kooperatif tipe jigsaw. Dengan batasan masalah Bedasarkan permasalahan yang telah dikemukakan di atas, dan agar penelitian ini lebih terfokus maka permasalahan dalam penelitian ini dibatasi pada hasil belajar ranah kognitif Pokok Bahasan Pendudukan Jepang

di Indonesia yang dipelajari pada semester 2 dalam Mata Pelajaran Sejarah di SMA Negeri 14 Batam Tahun Pelajaran 2013-2014.

Rumusan masalah adalah bagaimana hasil belajar siswa dalam mata pelajaran sejarah setelah penerapan pembelajaran kooperatif tipe Jigsaw di banding dengan dengan pembelajaran konvensional ? Penelitian ini bertujuan untuk mengungkapkan hasil belajar siswa pada mata pelajaran sejarah melalui pembelajaran kooperatif tipe Jigsaw di SMA Negeri 14 Batam dan mengetahui perbedaan hasil belajar kelas eksperimen dan kelas kontrol.

\section{B. METODE PENELITIAN}


Penelitian ini termasuk ke dalam jenis penelitian kuantitatif dengan pendekatan metode Quasi Experimental Design. Kelompokpertama yang dikenaiperlakuanberupa model pembelajaran kooperatif tipe jigsaw yaitu kelompok eksperimen. Kelompok kedua dikenai perlakuan yang berbeda adalah kelompok kontrol yaitu sebagai pembanding, menggunakan pembelajaran dengan metode ceramah. Subjek penelitian adalah siswa kelas XI IPS pada Mata Pelajaran Sejarah di SMA Negeri 14 Batam yang terdiri dari dua kelas yaitu XI IPS2 dan XI IPS3 yang berjumlah 61 siswa. Pada penelitian ini kelas XI IPS3 sebagai kelas eksperimen dengan pembelajaran kooperatif tipe jigsaw dan kelas XI IPS2 sebagai kelas kontrol yang pembelajarannya seperti biasa diterapkan guru sebelumnya (tidak diberlakukan seperti kelas eksperimen). Penentuan kelas kontrol dan kelas eksperimen tidak berdasarkan peringkat hasil belajar siswa sehingga tidak ada pengelompokkan siswa berprestasi tinggi atau siswa berprestasi rendah. Tetapi penentuan kelas ini dilakukan secara acak dari kelas yang sudah ada. Hal ini dilakukan karena tidak memungkinkan untuk mengubah kelas yang ada. Penentuan secara acak ini dapat dilakukan karena nilai rata-rata hasil belajar siswa dalam mata pelajaran sejarah kelas XI IPS semester I tidak berbeda secara signifikan.

Adapun variabel dalam penelitian ini adalah :

1. Hasil belajar kelas eksperiman, diambil dari nilai posttest siswa setelah dilaksanakan kegiatan pembelajaran kooperatif tipe jigsaw.

2. Hasil belajar kelas kontrol, diambil dari nilai posttest siswa setelah dilaksanakan kegiatan pembelajaran dengan metode konvensional.

Jenis data yang digunakan dalam penelitian ini adalah data primer, yaitu data hasil penelitian yang langsung dari subjek peneliti. Data dalam penelitian ini adalah hasil belajar Sejarah kelas XI IPS SMA Negeri 14 Batam setelah perlakuan diberikan. Sumber data dalam penelitian ini diambil dari test yang dilakukan diakhir penelitian pada kelas XI IPS dalam Mata Pelajaran Sejarah SMA Negeri 14 Batam.

Instrumen yang digunakan dalam penelitian ini adalah berupa soal test berbentuk objektif. Soal test dibuat berdasarkan kisi-kisi soal yang mengarah pada silabus dan rencana pelaksanaan pembelajaran mata pelajaran sejarah di SMA Negeri 14 Batam. Sebelum soal test digunakan maka dilakukan uji coba soal untuk mengetahui validitas, reliabilitas, tingkat kesukaran dan daya beda soal tersebut. Pengolahan data soal menggunakan program SPSS versi 16.0.

Uji coba soal dilakukan dikelas XI IPS 1 SMA Negeri 14 Batam. Hal ini dikarenakan kelas XI IPS SMA Negeri 14 Batam terdiri dari tiga kelas yang memiliki kurikulum dan kompetensi yang sama. 


\section{Hasil Penelitian}

Deskripsi data dari penelitian ini berupa data hasil penerapan pembelajaran Kooperatif tipe Jigsaw terhadap hasil belajar siswa dalam mata pelajaran sejarah kelas eksperimen dan kelas kontrol. Data hasil belajar berupa nilai untuk masingmasing siswa pada kelas eksperimen yang berjumlah 30 orang dan kelas kontrol berjumlah 30 orang. Nilai siswa pada kelas eksperimen berkisar antara 44 sampai dengan 96 sedangkan kelas kontrol berkisar antara 36 sampai dengan 88.

Berdasarkan analisis data, diperoleh nilai rata-rata (x), simpangan baku (s), dan varians (s2) siswa kelas eksperimen dan kelas kontrol sebagaimana dapat dilihat pada tabel berikut.

Tabel 1. Hasil Nilai Tertinggi, Terendah, Nilai Rata-rata, Simpangan Baku dan Varian.

\begin{tabular}{|l|l|l|l|l|l|l|}
\hline Kelas & $\begin{array}{l}\text { Kelas } \\
\text { Tertinggi }\end{array}$ & $\begin{array}{l}\text { Kelas } \\
\text { Terendah }\end{array}$ & $\mathrm{x}$ & $\mathrm{n}$ & $\mathrm{s}$ & $\mathrm{S} 2$ \\
\hline Eksperimen & 96 & 44 & 73,07 & 30 & 11,8814 & 141,1678 \\
\hline Kontrol & 88 & 36 & 66,66 & 30 & 11,6311 & 135,2827 \\
\hline
\end{tabular}

Analisis data dimaksud untuk mengetahui hasil belajar siswa melalui penerapan pembelajaran Kooperatif tipe Jigsaw terhadap hasil belajar siswa dalam mata pelajaran sejarah kelas XI IPS di SMA Negeri 14 Batam tahun pelajaran 2013/2014. Pada penelitian ini jika hasil belajar kelas eksperimen lebih besar dari kelas kontrol maka hipotesis analisis $\left(\mathrm{Ha}_{\mathrm{a}}\right.$ diterima dan hipotesis nol ( $\left.\mathrm{H}_{0}\right)$ ditolak. Data hasil penelitian di analisis menggunakan uji-t dengan terlebih dahulu melihatapakah subjek terdistribusi normal dan mempunyai varian yang homogen. Oleh karena itu terlebih dahulu dilakukan uji normalitas dan homogenitas. Agar dapat melihat apakah data dari kelas subjek penelitian terdistribusi normal maka dilakukan uji normalitas dengan menggunakan rumus Chi-Kuadrat dari pengujian di ketahui nilai X2 hitung dan X2 tabel untuk kedua kelas subjek pada taraf signifikansi $\alpha=0,05$ sebagaimana dapat dilihat pada tabel berikut.

Tabel 2. Hasil Perhitungan Normalitas

\begin{tabular}{|l|l|l|l|l|}
\hline Kelas & $\mathrm{n}$ & X hitung & X tabel & Distribusi \\
\hline Eksperimen & 30 & 5,26 & 11,07 & Normal \\
\hline
\end{tabular}




\begin{tabular}{|l|l|l|l|l|}
\hline Kontrol & 30 & 10,85 & 11,07 & Normal \\
\hline
\end{tabular}

Berdasarkan tabel di atas dapat ditarik kesimpulan bahwa distribusi data di kelas eksperimen dan kelas kontrol dinyatakan normal. Uji homogenitas untuk melihat apakah kedua kelas homogen atau tidak. Pengujian homogenitas data penelitian ini digunakan uji-t. Setelah dilakukan uji homogenitas diketahui nilai simpangan baku (s) dan varians (s2) pada kelas eksperimen dan kontrol. Agar lebih jelas dapat dilihat pada tabel berikut :

Tabel 3. Hasil Perhitungan Uji Homogenitas

\begin{tabular}{|l|l|l|l|l|l|l|}
\hline Kelas & $\mathrm{N}$ & $\mathrm{x}$ & $\mathrm{S}$ & $\mathrm{S}_{2}$ & Fhitung & Ftabel \\
\hline Eksperimen & 30 & 73,07 & 11,8814 & 141,1678 & 1,0435 & 1,85 \\
\hline Kontrol & 30 & 66,666 & 11,6311 & 134,9885 & 1,0435 & 1,85 \\
\hline
\end{tabular}

Fhitung dibanding dengan harga Ftabel dengan dk pembilang $=\mathrm{n}_{1}-1=30-1=29$ dan $\mathrm{dk}$ penyebut $=\mathrm{n}_{2}-1=30-1=29$. Pada taraf signifikan $5 \%$ dan $\mathrm{dk}$ pembilang sama dengan $\mathrm{dk}$ penyebut diperoleh Ftabel $=1,85$. Dengan demikian dapat dilihat bahwa Fhitung $<$ Ftabel $(1,0435<$ 1,85)sehingga dapat ditarik kesimpulan bahwa varian data dinyatakan homogen.

\section{Kesimpulan dan Saran}

\section{Kesimpulan}

Berdasarkan analisis data dan pembahasan di atas, maka dapat disimpulkan bahwa:

1. Setelah penerapan model pembelajaran Kooperatif tipe Jigsaw pada kelas eksperimen didapat rata-rata hasil belajar kelas eksperimen dan kelas kontrol. Rata-rata hasil belajar kelas eksperimen 73,07 sedangkan rata-rata hasil belajar pada kelas kontrol 66,66. Selain itu, jumlah siswa yang memenuhi Kriteria Ketuntasan Minimum (KKM) pada kelas eksperimen yaitu 21 orang dan kelas kontrol 11 orang. 
2. Setelah mengikuti pembelajaran terdapat perbedaan rata-rata hasil belajar pada kedua kelas dengan thitung 2,1084 dan ttabel 1,671 pada taraf signifikan 5\%. Jadi dapat disimpulkan bahwa hasil belajar kelas eksperimen dengan menggunakan model pembelajaran Kooperatif tipe Jigsaw memperoleh hasil belajar signifikan lebih tinggi dibandingkan dengan peserta didik yang mengikuti proses pembelajaran dengan menggunakan model pembelajaran konvensional.

\section{Saran}

Berdasarkan hasil penelitian yang telah dilakukan maka disarankan :

1. Pendidik disarankan untuk dapat memilih, mengembangkan, dan menerapkan berbagai aneka sumber belajar dan metode pengajaran dalam upaya memudahkan penyampaian materi pada peserta didik dan mengurangi berbagai hambatan dalam pembelajaran.

2. Bagi pihak sekolah dalam rangka memperbaiki dan meningkatkan kualitas pembelajaran dan meningkatkan mutu sekolah agar dapat menyediakan ruang khusus untuk praktek belajar sejarah seperti membuat miniaturminiatur peninggalan masa lampau sehingga peserta didik dapat mengetahui peristiwa-peristiwa yang telah terjadi pada masa lalu.

3. Untuk lebih efektifnya menggunakan metode dalam pengajaran, maka sangat disarankan kepada lembaga pendidikan untuk mengadakan seminarseminar mengenai metode dan model pembelajaran kepada guru-guru guna menjadikan guru-guru yang ada menjadi lebih kreatif dan inovatif dalamproses belajar mengajar.

\section{E. DAFTAR PUSTAKA}

Aunurrahman. 2008. Belajar dan Pembelajaran. Bandung : Alfabeta. 
Daryanto. 2013. Inovasi Pembelajaran Efektif. Bandung : Yrama Widya.

Mudjyahardjo Redja. 2001. Pengantar Pendidikan. Jakarta : Grafindo.

Rusman. 2013. Model-model Pembelajaran Mengembangkan Profesionalisme Guru. Jakarta : Rajawali Pers.

Sapriyani. 2009. Pembelajaran IPS. Bandung : Remaja Rosdakarya. 
